\title{
Melphalan in the Treatment of Myelomatosis
}

\author{
DOROTHY E. SPEED,* M.B., CH.B. ; D. A. G. GALTON,* M.A., M.D., M.R.C.P.
}

A. SWAN, $\dagger$ M.B., B.S., D.PATH.

Brit. med. F., 1964, 1, 1664-1669

This paper reports the results of 33 months' trial of melphalan ( $p$-di-(2-chloroethyl)amino-L-phenylalanine ; "alkeran") in the treatment of myelomatosis. This aromatic nitrogen mustard was synthesized by Bergel and Stock (1953). The racemic form, merphalan (sarcolysin), was synthesized in Moscow (Larionov, Khokhlov, Shkodinskaja, Vasina, Troosheikina, and Novikova, 1955). The trial started in December 1959, and 20 patients were first treated between that date and 1 March 1962 . This report includes observations made up to 1 September 1962, when seven patients had died. The shortest possible period of follow-up was thus six months. Three cases (Nos. 2, 3, and 13) have been reported elsewhere (Swan, 1962).

Table I shows the age and sex of the patients, the interval between the time of diagnosis and the start of melphalan therapy, the previous treatment received, the duration of observation of each patient after the start of melphalan therapy, and the number of courses of melphalan administered. The diagnosis had been established less than one year before the start of melphalan therapy in five cases, between one and two years in seven, and between two and six and three quarter years in eight. Two patients received only one course of melphalan, seven received two to five courses, 10 received 6 to 12 courses, and one received 19 . One patient receiving melphalan was observed for two and a half years, six were treated for 12 to 18 months, and 13 for less than one year. Seven patients had had no previous treatment for myelomatosis, while eight had received local $x$-ray therapy for the relief of pain. Three of

\begin{tabular}{|c|c|c|c|c|c|c|}
\hline \multirow[t]{2}{*}{$\begin{array}{l}\text { Case } \\
\text { No. }\end{array}$} & \multirow[t]{2}{*}{$\begin{array}{l}\text { Age } \\
\text { and } \\
\text { Sex }\end{array}$} & \multirow{2}{*}{$\begin{array}{c}\text { Interval } \\
\text { between } \\
\text { Diagnosis } \\
\text { and Start of } \\
\text { Melphalan } \\
\text { (Months) }\end{array}$} & \multirow[t]{2}{*}{$\begin{array}{l}\text { Previous } \\
\text { Treatment }\end{array}$} & \multirow{2}{*}{$\begin{array}{c}\text { Survival from } \\
\text { Start of } \\
\text { Melphalan } \\
\text { Treatment up } \\
\text { to } 1 / 9 / 62 \\
\text { (Months) }\end{array}$} & \multicolumn{2}{|c|}{$\begin{array}{c}\text { Courses of } \\
\text { Melphalan and } \\
\text { Total Dose } \\
\text { up to } 1 / 9 / 62 \\
\end{array}$} \\
\hline & & & & & No. & mg. \\
\hline 1 & $47 \mathrm{M}$ & 81 & Radiotherapy & 11 & 11 & 340 \\
\hline 2 & $48 \mathrm{~F}$ & 51 & $\begin{array}{l}\text { Methandienone. } \\
\text { Chlorambucil. } \\
\text { Stilboestrol }\end{array}$ & 33 & 19 & 1,348 \\
\hline 3 & $70 \mathrm{~F}$ & 36 & $\begin{array}{l}\text { Methandienone. } \\
\text { Chlorambucil. } \\
\text { Stilboestrol }\end{array}$ & $23 / 10 / 61 t$ & 5 & 307 \\
\hline 4 & $49 \mathrm{M}$ & 35 & $\begin{array}{l}\text { Radiotherapy. }{ }^{32} \mathrm{P} \\
\text { Cyclophosphamide }\end{array}$ & 10 & 4 & 274 \\
\hline 5 & $53 \mathrm{M}$ & 30 & $\begin{array}{l}\text { Urethane. Predni- } \\
\text { sone. A.C.T.H. } \\
\text { Radiotherapy }\end{array}$ & 16 & 10 & 660 \\
\hline 6 & $67 \mathrm{~F}$ & 26 & None & $\begin{array}{c}1 \\
31 / 12 / 61+\end{array}$ & 1 & 50 \\
\hline 7 & $53 \mathrm{M}$ & 26 & $\begin{array}{l}\text { Urethane. Radio- } \\
\text { therapy. } \\
\text { Nandrolone. } \\
\text { A.C.T.H. }\end{array}$ & $3 / 7 / 61 t$ & 8 & 510 \\
\hline $\begin{array}{l}8 \\
9\end{array}$ & $\begin{array}{l}46 \mathrm{M} \\
80 \mathrm{~F}\end{array}$ & $\begin{array}{l}25 \\
20\end{array}$ & None & 11 & 12 & $\begin{array}{l}770 \\
420\end{array}$ \\
\hline 10 & $62 \mathrm{M}$ & 18 & Radiotherapy & 12 & 10 & 250 \\
\hline 11 & $59 \mathrm{M}$ & 16 & Urethane & 8 & $\begin{array}{l}2 \\
\text { and } \mathrm{mair} \\
(2 \mathrm{mg} .\end{array}$ & $\begin{array}{r}369 \\
\text { enance } \\
\text { daily) }\end{array}$ \\
\hline $\begin{array}{l}12 \\
13\end{array}$ & $\begin{array}{l}63 M \\
56 M\end{array}$ & $\begin{array}{l}16 \\
14\end{array}$ & $\begin{array}{l}\text { Radiotherapy } \\
\text { None }\end{array}$ & $\begin{array}{c}8 \\
11 \\
5 / 2 / 62 t\end{array}$ & $\begin{array}{l}7 \\
4\end{array}$ & $\begin{array}{l}340 \\
320\end{array}$ \\
\hline $\begin{array}{l}14 \\
15 \\
16 \\
17 \\
18\end{array}$ & $\begin{array}{ll}59 & \mathrm{M} \\
75 & \mathrm{~F} \\
52 & \mathrm{~F} \\
52 & \mathrm{~F} \\
52 & \mathrm{M}\end{array}$ & $\begin{array}{r}13 \\
3 \\
13 \\
11 \\
6\end{array}$ & $\begin{array}{l}\text { "' } \\
\text { Prednisone } \\
\text { Radiotherapy } \\
\text { Stilbamidine }\end{array}$ & $\begin{array}{c}12 \\
10 \\
10 \\
6 \\
1 \frac{1}{2} \\
4 / 5 / 61 \dagger\end{array}$ & $\begin{array}{l}5 \\
6 \\
5 \\
3 \\
1\end{array}$ & $\begin{array}{r}145 \\
320 \\
270 \\
170 \\
50\end{array}$ \\
\hline 19 & $49 M$ & 3 & None & $\begin{array}{c}14 \\
27 / 4 / 62 t\end{array}$ & 8 & 460 \\
\hline 20 & $61 \mathrm{M}$ & 1 & Radiotherapy & $\begin{array}{c}13 \\
4 / 7 / 62 \dagger\end{array}$ & 9 & 590 \\
\hline
\end{tabular}

these patients and five others had also received one or more of the following: cyclophosphamide, chlorambucil, prednisone or corticotrophin, urethane, nandrolone, radioactive phosphorus, or stilbamidine. Two patients died within 6 months and five between 9 and 14 months after the start of the trial.

Table II shows the length of observation from the time of diagnosis of the seven previously untreated and the 13 treated patients. In the first group the median follow-up from the start of melphalan therapy was 11 months, in the second it was 10 months. The mean follow-up period was 10 months in the first and 11 months in the second group.

TABLE II.-Observation Period from Diagnosis to 1 September 1962 in 20 Cases of Myelomatosis

\begin{tabular}{|c|c|c|c|c|c|}
\hline \multicolumn{3}{|c|}{ Previously Treated } & \multicolumn{3}{|c|}{ Untreated } \\
\hline \multirow{2}{*}{$\begin{array}{l}\text { Case } \\
\text { No. }\end{array}$} & \multicolumn{2}{|c|}{$\begin{array}{l}\text { Observation Period } \\
\text { (Months) }\end{array}$} & \multirow{2}{*}{$\begin{array}{l}\text { Case } \\
\text { No. }\end{array}$} & \multicolumn{2}{|c|}{$\begin{array}{l}\text { Observation Period } \\
\text { (Months) }\end{array}$} \\
\hline & $\begin{array}{c}\text { From } \\
\text { Diagnosis }\end{array}$ & $\begin{array}{l}\text { From Start } \\
\text { of Melphalan } \\
\text { Therapy }\end{array}$ & & $\begin{array}{c}\text { From } \\
\text { Diagnosis }\end{array}$ & $\begin{array}{l}\text { From Start } \\
\text { of Melphalan } \\
\text { Therapy }\end{array}$ \\
\hline $\begin{array}{c}1^{*} \\
2 \\
3 \\
4^{*} \\
5^{*} \\
7^{*} \\
10^{*} \\
11 \\
12^{*} \\
16^{*} \\
17^{*} \\
18 \\
20^{*}\end{array}$ & $\begin{array}{l}92 \\
84 \\
44 \dagger \\
45 \\
46 \\
38 \dagger \\
30 \\
24 \\
24 \\
23 \\
17 \\
7 \frac{1}{2} \dagger \\
14 \dagger\end{array}$ & $\begin{array}{c}11 \\
33 \\
9 \dagger \\
10 \\
16 \\
12 \dagger \\
12 \\
8 \\
8 \\
10 \\
6 \\
1 \frac{1}{2} \dagger \\
13 \dagger\end{array}$ & $\begin{array}{r}6 \\
8 \\
9 \\
13 \\
14 \\
15 \\
19\end{array}$ & $\begin{array}{l}27 t \\
36 \\
37 \\
25 t \\
25 \\
13 \\
17 t\end{array}$ & $\begin{array}{l}1 \dagger \\
11 \\
17 \\
11 \dagger \\
12 \\
10 \\
14 \dagger\end{array}$ \\
\hline
\end{tabular}

\section{Condition Before Treatment}

Before treatment 10 patients were almost immobile and were confined to bed because of pain at varying sites, five had pain but were ambulant, and five had little or no pain; of the latter five, four complained of lassitude, breathlessness, and anorexia, while one presented with purpura and ecchymoses (Table III).

TABLE III.-Symptoms Before Start of Melphalan Therapy

\begin{tabular}{ll|l|l}
\hline \multicolumn{1}{c|}{ Symptoms } & No. of Patients & \multicolumn{1}{|c}{ Case No. of Patients } \\
\hline Confined to bed with pain &. & 10 & $2,3,4,5,7,9,10,15,17,19$ \\
In pain but ambulant & $\cdots$ & 5 & $1,11,12,13,20$ \\
Symptoms of anaemia & $\cdots$ & 5 & $6,8,14 * 16,18$ \\
\hline & \\
\hline
\end{tabular}

The reasons for trying melphalan were as follows: six patients (Cases 1, 4, 5, 7, 10, and 12) had received radiation therapy to two or more sites, but pain had become widespread without being dominant at any one site, so that radiotherapy was not thought practicable, except to relieve local pain in one case. Two others (Cases 17 and 20) also had generalized pain but had received only one course of palliative irradiation to single sites. Four untreated patients (Cases 9, 13, 15, and 19) had

* Chester Beatty Research Institute, Institute of Cancer Research, Fulham Road, London. t St. James' Hospital, Balham, London. 
widespread pain, and three similar patients (Cases 2, 3, and 11) had shown no objective response to previous treatment with urethane (Case 11) or chlorambucil (Cases 2 and 3). Five patients (Cases 6, 8, 14, 16, and 18) were treated because they were anaemic. One (Case 14) also had extensive purpura and ecchymoses. These five patients did not complain of pain.

\section{Dosage}

Administration was in the form of tablets of $2 \mathrm{mg}$. and $5 \mathrm{mg}$. Fourteen patients received short courses lasting five to seven days at a daily dose of $10 \mathrm{mg}$. (total dose approximately $1 \mathrm{mg}$. $/ \mathrm{kg}$. of body weight). Further courses of 50 to $70 \mathrm{mg}$. were administered at intervals of four to eight weeks; in most cases courses were given at approximately six-week intervals, and were repeated as long as the treatment was thought to be beneficial, and not damaging to the bone-marrow. The total dose received varied from 50 to $1,348 \mathrm{mg}$. (see Table I). Two patients (Cases 10 and 14) received a daily dose of $5 \mathrm{mg}$. for four to six days; three patients (Cases 2,3, and 13) received two to eight courses of $5 \mathrm{mg}$. for 7 to 14 days with intervals of one to three weeks between each course ; finally, one patient (Case 11) received $2 \mathrm{mg}$. daily for 100 days after an initial course of $165 \mathrm{mg}$. administered during 31 days.

Ancillary Treatment.-Thirteen patients (Cases 1, 4, 6, 7, 8, $9,11,12,13,15,18,19$, and 20 ) received no other treatment than blood transfusions and analgesics, while seven (Cases 2, 3, $5,10,14,16$, and 17) received at various times one or more of the following: prednisone, adrenocorticotrophin, methandienone, nandrolone, or stilboestrol. Five patients (Cases 5, $7,15,17$, and 19) received local radiotherapy to single painful sites, on two occasions in one case.

\section{Side-effects and Toxicity of Melphalan}

Melphalan was well tolerated. Five patients experienced nausea and vomiting at the end of the first and second courses; one patient, a woman aged 75 , had temporary partial loss of scalp hair. There was one haemorrhagic incident (Case 10), but no major infective episodes occurred during treatment. There was no deterioration in renal function where renal damage already existed.

\section{Bone-marrow Depression}

Haemoglobin Concentration.-Seven patients showed a persistent fall in haemoglobin throughout treatment and required multiple transfusions (Cases 1, 3, 6, 8, 10, 16, and 18); the blood urea was raised in five of these persistently anaemic patients.

Neutrophil Count.-After the first course of melphalan there was in all cases a fall in the neutrophil count ranging from 20 to $90 \%$ of the initial count. The fall was usually maximal between two and three weeks of the start of treatment, and the counts had in most cases returned to normal four to six weeks after the time of the greatest depression. Seven out of 18 patients who received further courses of melphalan did not again show a fall in the neutrophil count. The lowest falls in the neutrophil count after the first course of treatment, or in Case 7 after two courses administered in 25 days, occurred in six cases in association with a raised blood-urea concentration (Cases 6, 7, 9, 15, 18, and 19). The lowest recorded counts were $240,700,320,750,1,100$, and 1,200/c.mm. Radiotherapy was administered at the same time as, or within a few days of, melphalan in Cases 7, 15, and 19. In Case 9 (see Case Report below) the neutrophil count fell to $200 /$ c.mm. 40 days after the start of the second course of melphalan. The bloodurea concentration fell to normal values during the ensuing six months, and the neutrophil count did not fall after any of the six courses of melphalan administered 16 months after the second course. In Case 19 the neutrophil count fell to 980/ c.mm. six weeks after the start of the second course of melphalan, when the blood-urea concentration was normal.

Platelets.-Platelet counts fell below 100,000/c.mm. in seven cases, in six instances after the first course of treatment. The lowest recorded counts in these six cases were $18,000,74,000$, 90,000, 60,000, 68,000, and 90,000/c.mm. (Cases 6, 9, 12, 14, 15 , and 18). In four cases the blood-urea concentration was raised, and one patient also received concurrent radiotherapy. Four of these six patients received further courses of melphalan, but did not again become thrombocytopenic.

The lowest recorded platelet count was 10,000/c.mm. in Case 10, the only patient who had transient purpura and ecchymoses. This occurred after the tenth course of treatment, and the blood urea concentration was over $100 \mathrm{mg} . / 100 \mathrm{ml}$. Before treatment the platelet count was $170,000 /$ c.mm.

\section{Clinical}

\section{Results}

Evidence of improvement was sought in the amount of relief from pain, gain in weight, and increase in mobility, Improvement was easiest to assess in those patients who were relieved of pain, having been immobilized with generalized pain ; it was more difficult to assess in those with less severe symptoms, and in the five who received concurrent radiotherapy.

Relief of pain was striking in 10 patients (Cases 1, 2, 4, 7, 9, $10,11,15,19$, and 20), occurring within 7 to 14 days of the start of the first course in seven patients, but not until two or three courses had been administered in three. Pain was relieved for varying periods, usually for two to three weeks.

Analgesics were required less frequently after a four- to sixmonth period of treatment with melphalan, and five patients were able to dispense with them thereafter. Others were at their best about six months after the start of treatment, but subsequently failed to secure relief of pain ; one patient (Case 2), who received 19 courses of treatment, had practically no pain for two and a half years; she occasionally had backache after a hard day's housework. Another (Case 5) did not become free of pain for 16 months, when he had received 10 courses.

Seven of 10 bedridden patients (Table III) were able to get up. Two bedridden patients received radiotherapy to the pelvis concurrently with their first course of melphalan (Cases 5 and 17) ; it was therefore difficult to assess how far melphalan was responsible for their initial improvement, though subsequently both remained mobile and active without analgesics; finally, one patient (Case 3) had no relief of back pain ; she remained bedridden because of a pathological fracture of the femur.

Eight patients gained 4 to $16^{\prime} \mathrm{lb}$. (1.8 to $7.3 \mathrm{~kg}$.) in weight (Cases 2, 4, 5, 7, 9, 11, 15, and 19) ; none of these was receiving steroid therapy ; six lost weight (Cases $3,6,8,10,16$, and 18).

\section{Radiological Changes}

Serial $x$-ray films of the skeleton remained unchanged or showed an increase in the number and size of the lesions, as in the case of the patient (Case 2) observed for 33 months, whose pains were completely relieved and who returned to normal household activities. Recalcification did not occur except at the site of local $x$-irradiation in one case.

\section{Laboratory Findings}

Anaemia.-Before treatment the haemoglobin concentration was above 10 g. $/ 100 \mathrm{ml}$. in 11 cases (Cases $1,4,5,6,7,12,13$, $14,15,17$, and 20 ), and below $10 \mathrm{~g} . / 100 \mathrm{ml}$. in nine. An 
increase occurred in four of the former (Cases 4, 5, 7, and 15) and in four of the latter (Cases 2, 9, 11, and 19). Blood transfusions had been administered at the start of treatment in Cases 2, 5, 9, 11, 15, and 19, and once later in Cases 5 and 11. The haemoglobin increase continued long after the maximal survival of the transfused red cells (see Chart). Seven of the remaining 12 patients required repeated transfusions (Cases 1 , $3,6,8,10,16$, and 18). The patients whose haemoglobin rose secured gains of 1 to $4.5 \mathrm{~g} . / 100 \mathrm{ml}$., the maximum values being attained three to six months after treatment.

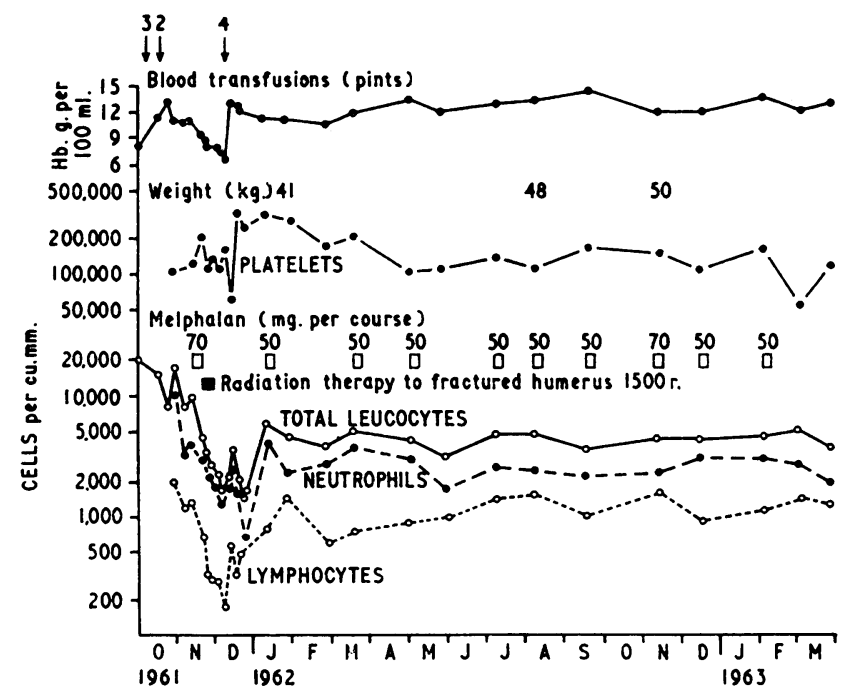

Case 15. Changes in weight, haemoglobin concentration, platelet, total leucocyte, neutrophil, and lymphocyte counts during melphalan therapy.

Bone-marrow.-The percentage of plasma cells in the bonemarrow films was less after treatment in several cases. For example, in Case 2, where both samples were obtained from the same site in the sternum, it fell from $40 \%$ before treatment to $10 \% 28$ months after the start of treatment. In other cases the fall was less significant, and repeat punctures were sometimes made at different sites from the first, so that comparison could not be made. In Case 19, a patient whose pains were relieved and whose haemoglobin concentration had increased, films of iliac crest bone-marrow showed a threefold increase in the percentage of plasma cells nine months after the start of melphalan therapy.

Plasma Proteins, Blood Urea, Serum Calcium, Erythrocyte Sedimentation Rate, and Urinary Protein Levels.- Samples of blood and urine were taken at intervals varying from 2 to 10 months of the start of melphalan therapy. Four patients (Cases 2, 5, 15, and 19) showed a fall in the amounts of abnormal globulins, in the erythrocyte sedimentation rate, in the blood-urea concentration, in the serum calcium and urinary protein, where these had been raised; the values remained unchanged in five cases (Nos. 1, 4, 7, 9, and 11) and showed progressive deterioration in 11 (Nos. $3,6,8,10,12,13,14,16$, 17,18 , and 20).

\section{Case 5}

\section{Illustrative Case Reports}

A man aged 53 was investigated in April 1960 for severe pain in the neck. Extensive osteolytic deposits throughout the skeleton were demonstrated radiologically, and $75 \%$ of the cells in bonemarrow films were atypical plasma cells. He received urethane, prednisone, and also radiotherapy to the cervical and lumbar spine with relief of pain. In March 1961 he received further radiotherapy and a short course of corticotrophin injections. In April 1961 he was admitted to the Royal Marsden Hospital with severe generalized pain and pneumonia.

Investigations.-A blood count showed: $\mathrm{Hb}, 10.3 \mathrm{~g} . / 100 \mathrm{ml}$; W.B.C., 3,900/c.mm. (neutrophils 3,000, lymphocytes $620 /$ c.mm.); platelets, 210,000/c.mm. ; E.S.R., $16 \mathrm{~mm}$. in first hour (Wintrobe); serum proteins, $11.4 \mathrm{~g} . / 100 \mathrm{ml}$. (albumin 2.2 g., globulin $9.2 \mathrm{~g}$.); and paper electrophoresis showed a compact gamma band; serum calcium, $10.6 \mathrm{mg} . / 100 \mathrm{ml}$; blood urea, $33 \mathrm{mg} . / 100 \mathrm{ml}$. The urine was protein-free. Radiologically, extension of the osteolytic lesions had occurred throughout the skeleton.

Treatment and Progress.-A blood transfusion of 2 pints $(1,140$ ml.) was given on 20 April. Irradiation therapy to the right hip was carried out in May and again in October. From 25 April 1961 to 1 September 1962 he received 10 courses of melphalan, at a daily dose of $10 \mathrm{mg}$., the total dose being $50 \mathrm{mg}$. in two courses and $70 \mathrm{mg}$. in the remainder. The intervals between the courses were from 3 to 11 weeks. Profuse bleeding from haemorrhoids in September 1961 led to a fall in haemoglobin to $7.3 \mathrm{~g} . / 100 \mathrm{ml}$. A transfusion of 2 pints $(1,140 \mathrm{ml}$.) of blood was given on 7 October 1961. By November his general condition had improved and he could walk with a stick. The haemoglobin increased to $12 \mathrm{~g} . / 100 \mathrm{ml}$. and continued to rise. The serum globulin had fallen to $4.4 \mathrm{~g} . / 100 \mathrm{ml}$., the serum calcium was $9.8 \mathrm{mg} . / 100 \mathrm{ml}$., and the blood urea $17 \mathrm{mg} . / 100 \mathrm{ml}$. Radiologically, further increase in the size and number of lesions was demonstrated in the pelvis and femora, and there was further collapse of vertebral bodies. Symptomatic improvement continued in the ensuing year although he never became entirely free of pain, requiring occasional doses of analgesics on most days. The haemoglobin concentration remained at normal levels from December 1961, and his weight increased by over $20 \mathrm{lb}$. $(9 \mathrm{~kg}$.). The platelet count remained above $100,000 /$ c.mm. throughout the observation period, and the lowest recorded neutrophil count was $900 / \mathrm{c} . \mathrm{mm}$. five weeks after the fifth course of melphalan, which was given within one week of radiation therapy to the hip.

Comment.-This patient improved only slightly in the first six months, and was at his best in the following year. $\mathrm{He}$ tolerated repeated courses of melphalan, but became neutropenic when melphalan was administered within one week of a course of radiotherapy.

\section{Case 6}

A woman of 67 was admitted to the Royal Marsden Hospital with pain in the back of three weeks' duration. Myelomatosis had been diagnosed 14 months previously and she had received a blood transfusion and iron therapy. Radiologically no bone lesions were demonstrable.

Investigations.-A blood count showed: $\mathrm{Hb}, 10.4 \mathrm{~g} . / 100 \mathrm{ml}$.; W.B.C., 3,300/c.mm. (neutrophils 1,200 ) ; platelets, $160,000 / \mathrm{c} . \mathrm{mm}$. The bone-marrow was fatty, and $20 \%$ of the cells were poorly differentiated plasma cells with large nucleoli. The serum proteins were 8.4 g./100 ml. (albumin 3.6 g., globulin 4.8 g.). Paper electrophoresis showed a compact gamma band. Blood urea was $82 \mathrm{mg} . / 100 \mathrm{ml}$.

Treatment and Progress.-A blood transfusion of 2 pints $(1,140$ ml.) was administered on 22 November 1961, and melphalan, 10 mg. daily, for five days from 30 November. The back pain had decreased one week later, but pyelitis developed, due to Escherichia coli, and failed to respond to penicillin and tetracycline. The blood urea increased to $200 \mathrm{mg} . / 100 \mathrm{ml}$. on 27 December and the patient died on 31 December. The platelet count fell to $80,000 / \mathrm{c} . \mathrm{mm}$. on 13 December, and to 18,000 on 28 December, while the neutrophil count fell to 540 on the 14th and to 240 on the 28th.

A post-mortem examination revealed bilateral pyelonephritis, and the bone-marrow was diffusely infiltrated with myeloma cells.

Comment.-This case illustrates the extreme sensitivity to melphalan in the presence of impaired renal function.

\section{Case 9}

A woman aged 80 had become bedridden with severe backache, which she had had for three months.

Investigations. $-X$-ray films of the skeleton revealed osteoporosis, and the bodies of the twelth thoracic and first lumbar veretebrae were collapsed. There were osteolytic deposits in the skull and the left side of the pelvis. A blood count showed: $\mathrm{Hb}, 9 \mathrm{~g} . / 100 \mathrm{ml}$. ; W.B.C., 2,100/c.mm. (neutrophils 820 ); platelets, 230,000/c.mm. Investigation of the bone-marrow showed $15 \%$ of the nucleated 
cells to be well-differentiated plasma cells, and the iron stores were abundant; E.S.R., $130 \mathrm{~mm}$. in the first hour; serum proteins, 7.2 g. $/ 100 \mathrm{ml}$. (albumin $2.6 \mathrm{~g}$., globulin $4.6 \mathrm{~g}$.). Paper electrophoresis revealed a compact band between the $\beta$ and $\gamma$ regions, and the protein was identified as a cryoglobulin. Serum calcium was 8.8 mg. $/ 100 \mathrm{ml}$; blood urea, $100 \mathrm{mg} . / 100 \mathrm{ml}$. A trace of protein was present in the urine.

Treatment and Progress.-Eight courses of melphalan were aaministered between 16 March 1961 and 1 September 1962. The daily dose was $10 \mathrm{mg}$., the total dose being $70 \mathrm{mg}$. in the first and $50 \mathrm{mg}$. in the subsequent courses, the intervals between courses varying from 7 to 11 weeks. On 10 April 1961 the $\mathrm{Hb}$ had fallen to $6 \mathrm{~g} . / 100 \mathrm{ml}$. and blood transfusions were administered on 11 and 25 April and 5 July. By 6 April she had no pain and in the ensuing months was able to walk with the help of sticks. From November 1961 she was able to walk without sticks. From August 1961 to September 1962 the $\mathrm{Hb}$ was maintained at approximately $12 \mathrm{~g} . / 100 \mathrm{ml}$. except for an unexplained fall to $7 \mathrm{~g}$. in February 1962 , when she received a further transfusion. Subsequent $x$-ray films showed further collapse of vertebral bodies but little change in the skull and pelvic lesions. In May 1962 the E.S.R. was $40 \mathrm{~mm}$., the serum globulin was $6.7 \mathrm{~g} . / 100 \mathrm{ml}$., and the serum calcium $9.3 \mathrm{mg} . / 100 \mathrm{ml}$. Blood urea was $35 \mathrm{mg} . / 100 \mathrm{ml}$. Three subsequent bone-marrow examinations showed no significant change. The platelet count fell to $74,000 /$ c.mm. 21 days after the start of the first course of melphalan, but did not fall below 100,000 thereafter. The neutrophil count fell to $320 /$ c.mm. 36 days after the start of the first course of melphalan, and to 20040 days after the start of the second. Subsequently the neutrophil count remained between 440 and $2,500 /$ c.mm., but showed a general upward trend.

Comment.-This patient obtained striking and prolonged relief of pain, and sustained increase in the haemoglobin concentration. Local radiotherapy was not required. There was no radiological improvement, and the serum globulin level increased. The platelet count fell slightly after the first course of melphalan only, the neutrophil count fell considerably after the first two courses, when the blood urea was raised. Five further courses were well tolerated.

\section{Case 15}

A woman of 75 complained in August 1961 of pain in the back, right arm, and both legs, which became progressively severe. She was confined to bed in October 1961. She was investigated elsewhere, a bone-marrow biopsy leading to a diagnosis of myelomatosis; and after receiving two blood transfusions she was transferred to the Royal Marsden Hospital on 10 November.

Investigations.-On 12 November a blood count showed: $\mathrm{Hb}$, 10.9 g./100 ml. ; W.B.C., 10,000/c.mm. (neutrophils 4,300/c.mm., mononuclear cells (including plasma cells and lymphocytes) $5,200 /$ c.mm.) ; platelets, $131,000 /$ c.mm. Bone-marrow films showed $80 \%$ of the nucleated cells to be well-differentiated plasma rells, lymphocytes, and intermediate cells. E.S.R. was $63 \mathrm{~mm}$. in the first hour; serum protein, $6.3 \mathrm{~g} . / 100 \mathrm{ml}$. (albumin $4.2 \mathrm{~g}$., globulin $2.1 \mathrm{~g}$.). Blood urea was $67 \mathrm{mg} . / 100 \mathrm{ml}$. ; serum calcium, $14.6 \mathrm{mg} . / 100 \mathrm{ml}$. There was a trace of protein in the urine. $X$-ray films of the pelvis, lumbar spine, and long bones showed extensive deposits and a pathological fracture of the right ischium.

Treatment and Progress (see Chart).-A blood transfusion was administered on 11 December 1961. A pathological fracture of the right humerus on 21 November was treated by local $x$ irradiation from 22 to 30 November. Between 15 November 1961 and 28 February 1963 she had received 10 courses of melphalan. The intervals between the courses varied from 24 days to 9 weeks; -the daily dose was $10 \mathrm{mg}$.- - two courses lasting seven days and five lasting five days. The pain improved rapidly, and she was almost free of pain when discharged from hospital on 22 December 1961, but still required assistance for walking. Improvement continued and she gained weight. Further $x$-ray films of the skeleton in September 1962 showed an increase in the size and number of deposits.

Comment.-This patient obtained prolonged relief of widespread pain, gain in weight, and sustained increase in the haemoglobir concentration, but skeletal $x$-ray films showed progressive extension of the lesions. Neutropenia was marked only after the first course of melphalan, at the start of which the blood-urea concentration was raised; concurrent radiotherapy was given for the relief of local pain. The platelet count fell transiently.

\section{Discussion}

The basic abnormality in myelomatosis is the progressive proliferation of abnormal plasma cells, the principal consequences of which are, first, the development of progressive destructive lesions of the skeleton resulting in pain and orthopaedic deformities; second, progressive replacement of the bone-marrow resulting in varying degrees of haemopoietic insufficiency ; and third, long-continued proteinuria and hypercalcuria with resulting renal damage. If the proliferation of the myeloma cells could be arrested the advance of the disease would be arrested also, though established structural damage to skeletal and renal tissue would be largely irreversible. Unfortunately the available forms of treatment are not very effective.

Radiotherapy usually relieves local pain and may cause local recalcification; but it does not affect the course of the disease and is not practicable when pain is generalized. Urethane has had a longer trial than any other drug (Alwall, 1947 ; Loge and Rundles, 1949 ; Luttgens and Bayrd, 1951) and is effective in about one case in six. In patients who respond, pain is relieved and the haemoglobin concentration increases, while $i$ 'e percentage of myeloma cells in the bone-marrow falls; the erythrocyte sedimentation rate and the level of abnormal serum globulin fall and the proteinuria decreases. Recalcification of skeletal lesions is exceptional. Urethane is not a satisfactory drug because, while few patients respond, many complain of flatulence, anorexia, nausea, and vomiting. Skipper (1949) found that urethane and nitrogen mustard were synergistic in their effect on a murine leukaemia, and Innes and Rider (1955) found that urethane was effective at a lower dose than was usually required when administered in combination with a nitrogen mustard to 17 patients suffering from myelomatosis. After nine years' experience with this combination, however, Innes (1963) reported considerable improvement in only $17 \%$ of 84 cases, and did not think that the progress of the disease had been arrested.

Blokhin, Larionov, Perevodchikova, Chebotareva, and Merkulova (1958) reported some regression in three out of six cases of myclomatosis, with recalcification of the skeletal lesions in one case, following treatment with DL-phenylalanine nitrogen mustard ("sarcolysin"). The biological activity of this substance is mainly due to the L-component (melphalan) which we have used in the present trial.

\section{Present Series}

The assessment of therapy in myelomatosis is difficult because relief of pain, the commonest symptom, is so difficult to evaluate, because the indications for treatment and the rate of progression of the disease vary from case to case, and because most patients receive more than one form of treatment during the course of their disease. Thus the same criteria of assessment cannot be applied to every case. In our series, 15 patients were treated because of pain, five because of anaemia. Melphalan therapy was begun within one year of diagnosis in five cases, but eight patients were known to have had myelomatosis for between two and six and a half years before the start of melphalan.

Table IV shows the 12 patients who obtained some favourable response attributable to melphalan therapy, the factors considered being relief of pain, gain in weight, haemoglobin increase, and significant and persistent decrease in the erythrocyte sedimentation rate, serum globulin and calcium levels, blood urea concentration, and proteinuria. Four patients, one bedridden, secured pain relief, but showed no objective evidence of 
benefit ; four patients, three of them bedriden, were relieved of pain, became ambulant, gained weight, and had an increase in their haemoglobin concentration, but the biochemical findings showed no significant change; the four patients who showed favourable changes in the biochemical findings also improved symptomatically, gained weight, and secured an increase in the haemoglobin concentration. All of the eight patients whose haemoglobin concentration increased had been treated primarily

\begin{tabular}{|c|c|c|c|c|}
\hline $\begin{array}{l}\text { Case } \\
\text { No. }\end{array}$ & \begin{tabular}{|c|} 
Relief of \\
Generalized \\
Pain \\
(12 of 15 Cases $)$
\end{tabular} & $\begin{array}{c}\text { Weight } \\
\text { Gain }\end{array}$ & $\begin{array}{l}\text { Increase in } \mathrm{Hb} \\
\text { Concentration }\end{array}$ & $\begin{array}{c}\text { Favourable } \\
\text { Changes in } \\
\text { Biochemical } \\
\text { Findings }\end{array}$ \\
\hline $\begin{array}{r}1 \\
17 \\
20 \\
10 \\
11 \\
4 \\
9 \\
7 \\
5 \\
2 \\
15 \\
19\end{array}$ & $\begin{array}{l}+ \\
+t \\
+ \\
+* \\
+ \\
+* \\
+* \\
+{ }^{*}+ \\
++ \\
+* \\
+{ }^{*}+ \\
+^{*}+\end{array}$ & $\begin{array}{l}+ \\
+ \\
+ \\
+ \\
+ \\
+ \\
+ \\
+\end{array}$ & $\begin{array}{l}+ \\
+ \\
+ \\
+ \\
+ \\
+ \\
+ \\
+\end{array}$ & $\begin{array}{l}+ \\
+ \\
+ \\
+\end{array}$ \\
\hline
\end{tabular}

because of pain, and none of the five who were treated only because they were anaemic responded. Radiological improvement was not observed in any case, even in the patient observed for the longest period (Case 2), and no conclusion could be drawn from the small number of bone-marrow examinations repeated during treatment. It is reasonable to suppose, however, that the favourable effects described reflected some interference with the proliferation of the myeloma cells.

\section{Other Series}

Bergsagel (1962) and Bergsagel, Sprague, Austin, and Griffith (1962) reported the results of a co-operative comparative study by the South-Western Cancer Chemotherapy Study Group in which melphalan proved to be the most effective of the five drugs tested; the others were mitomycin $\mathrm{C}$, carbamic acid (bis(1-aziridinyl)phosphinyl)ethyl ester, aminocyclopentanecarboxylic acid, and meta-DL-phenylalanine nitrogen mustard. Bernard, Seligmann, and Danon (1962) reported beneficial effects in four out of 17 cases, while Videbaek (1962) obtained "remarkably favourable results" in five out of 30 cases. Waldenström (1964) paid particular attention to the changes in the serum-protein pattern during melphalan therapy in 49 cases. Favourable changes occurred in 33 of the 41 cases in which the pattern was abnormal before the treatment was begun. Waldenström regards melphalan as the best drug now available in the treatment of myelomatosis.

\section{Practical Considerations}

The only acceptable way to establish marginal differences between methods of treatment of the same order of efficacy is by means of the controlled clinical trial ; and while melphalan has already been found to be the most effective of the five drugs compared in Bergsagel's report, urethane itself, and cyclophosphamide, reported to be of value by Matthias, Misiewicz, and Scott (1960), have not been included in a comparative trial.

We have been impressed by the necessity of persisting with melphalan therapy in each case, for improvement may be slow but sustained after an apparently unpromising start, the optimal condition being attained only after many months. The chief disadvantage of melphalan therapy is the toxicity to the bonemarrow which results from the same cytotoxic property on which its therapeutic effect almost certainly depends. The administration of courses of treatment at intervals of four to eight weeks has proved to be safe, provided that the ordinary precautions appropriate to all cytotoxic drug therapy are observed, and, in addition, that reduced dosage is used for uraemic patients. These patients are particularly vulnerable, perhaps because the rate of excretion of the drug is decreased. Melphalan therapy should be postponed until renal failure has been corrected so far as is possible. We prefer to withhold melphalan therapy during a course of radiotherapy and for the ensuing month, also in the presence of persistent neutropenia or thrombocytopenia resulting from the disease or from previous chemotherapy.

Bergsagel recommends intermittent therapy, each course consisting of four daily doses of $0.25 \mathrm{mg}$. $/ \mathrm{kg}$. body weight. Waldenström (1964) prefers continuous therapy at a daily dose of $2 \mathrm{mg}$. after an initial period of about three weeks at a daily dose of $5 \mathrm{mg}$. Favourable changes in the serum-protein pattern occurred in a much larger proportion of cases than in our series: this method of administration would appear to be more effective if the serum-protein changes reflect the proliferative activity of the myeloma cells. But spontaneous increase in the haemoglobin concentration was more frequent in our series, perhaps because erythropoiesis is suppressed by the continuous administration of melphalan. However, persistent moderate anaemia may be an acceptable price for better overall control of the disease. In practice blood counts are required less of ten by patients receiving intermittent therapy. In uncomplicated cases fortnightly counts are sufficient during the first 10 weeks, and monthly counts thereafter. The bedridden patients in our series had more frequent counts when they were in hospital. Waldenström (personal communication) considers twice-weekly blood counts to be necessary for patients receiving continuous therapy. If further trials confirm the impression that melphalan therapy is beneficial in myelomatosis, a scheme of dosage somewhere between these two may be found to be the best compromise between maximum efficiency and practicability.

\section{Summary}

Twenty patients suffering from myelomatosis have been treated with melphalan, L-phenylalanine nitrogen mustard.

The minimum period of follow-up was six months, and eight patients were observed for 12 to 33 months. Seven patients died between 1 and 14 months after starting treatment.

Pain was relieved in 11 out of 15 cases, the haemoglobin concentration increased in eight cases, and significant decrease in the erythrocyte sedimentation rate, serum globulin level, serum calcium level, and proteinuria occurred in four cases.

Melphalan is a bone-marrow depressant. A fall in the neutrophil count occurred in all cases, and in the platelet count in seven cases. Melphalan was more toxic in the presence of uraemia.

This investigation has been supported by grants to the Chester Beatty Research Institute (Institute of Cancer Research, Royal Cancer Hospital) from the Medical Research Council, the British Empire Cancer Campaign, the Anna Fuller Fund, and the National Cancer Institute of the National Institutes of Health, U.S. Public Health Service.

We wish to thank the consultant staff of the Royal Marsden Hospital and St. James' Hospital, Balham, for referring patients for treatment ; Dr. S. T. Callender for allowing us to include Case 11 ; and Dr. J. H. O. Earle and Dr. Eunice Lockey for allowing us to include Cases 1, 10, and 14.

Addendum.-The following patients have since died: Case 1 (4 September 1962); Case 2 (23 July 1963); Case 5 (5 February 1964); Case 8 (23 March 1963); Case 9 (9 March 1964); 
Case 10 (19 October 1962); Case 12 (24 February 1964); Case 14 (9 September 1962); and Case 16 (17 February 1963). Case 5 received 10 further courses of melphalan, and the disease remained well controlled until the last 10 weeks of life, when the growth extended extremely rapidly. He received one further course of radiotherapy for local pain. Case 9 received eight further courses of melphalan, and the disease was well controlled except for local pain from pathological fractures of ribs which was relieved by irradiation. At post-mortem examination a gastric carcinoma, suspected in the last three months of life, was found. Cases 8, 9, 12, 14, and 16 did not benefit from melphalan therapy. Seven further patients have been treated, four of whom obtained relief of pain for periods up to 16 months; one did not respond to melphalan or to cyclophosphamide, and required repeated courses of local irradiation; two patients in renal failure failed to respond, and in one case profound and prolonged neutropenia and thrombocytopenia followed each of two courses of melphalan lasting 14 and 7 days at a daily dose of $5 \mathrm{mg}$.

\section{REFBRENCES}

Alwall, N. (1947). Lancet, 2, 388.

Bergel, F., and Stock, J. A. (1953). A.R. Brit. Emp. Cancer Campgn, 31, 6.

Bergsagel, D. E. (1962). Cancer Chemother. Rep., No. 16, p. 261.

Sergsagel, D. E. C. C., Austin, C., and Griffith, K. M. (1962). Ibid., No. 21, p. 87.

Bernard, J., Seligmann, M., and Danon, F. (1962). Nouv. Rev. franç. Hémat., 2, 611 .

Blokhin, N., Larionov, L., Perevodchikova, N., Chebotareva, L., and Merkulova, N. (1958)." Ann. N.Y. Acad. Sci., 68, 1128.

Innes, J. (1963). Proc. roy. Soc. Med., 56, 648.

and Rider, W. D. (1955). Blood, 10, 252.

Larionov, L. F., Khokhlov, A. S., Shkodinskaja, E. N., Vasina, O. S., Troosheikina, V. I., and Novikova, M. A. (1955). Bull. exp. Biol. Med. (N.Y.), 1, 48 .

Loge, J. P., and Rundles, R. W. (1949). Blood, 4, 201.

Loge, J. P., and Rundles, R. E. D. (1951). F. Amer. med. Ass., 147, 824. Matthias, J. Q., Misiewicz, J. J., and Scott, R. B. (1960). Brit. med. F.,

2, 1837. . (1949). Cancer, 2, 475.

Swan, A. (1962). Proceedings of Eighth Congress of European Society of Haematology, p. 162. Karger, Basle.

Videbaek, A. (1962). Proceedings of Ninth Congress of the International Society of Haematology. In press.

Waldenström, J. (1964). Brit. med. f., 1, 859.

\title{
Subcutaneous Phycomycosis : A Review of 31 Cases Seen in Uganda
}

\author{
D. P. BURKITT,* M.D.; F.R.C.S.ED. ; A. M. M. WILSON,* B.A., B.M., B.CH., DIP.BACT. \\ D. B. JELLIFFE, $*$ M.D., F.R.C.P.
}

[With Special Plate]

Brit. med. F., 1964, 1, 1669-1672

Subcutaneous phycomycosis is an infection of the subcutaneous fat by a fungus of the family Entomophthoraceae, usually of the genus Basidiobolus, that results clinically in a slowly increasing painless area of subcutaneous induration which is small initially but can sometimes reach very large dimensions.

The clinical syndrome of subcutaneous phycomycosis was first reported from Indonesia by Lie Kian Joe et al. (1956). Subsequently eight further cases were reported from Indonesia (Lie Kian Joe et al., 1959, 1960, 1962 ; Symmers, 1960 ; Lie Kian Joe and Nio-Injo Tjoei Eng, 1960). Six cases have now been reported from Africa: two of these from Uganda (Jelliffe et al., 1961, 1962), one from Kenya (G. Neville and R. Miller, personal communication, 1962), one from the Cameroons (Blanche et al., 1961), one from the northern Sudan (Lynch and Husband, 1962), and one from Nigeria (Elebute and Okubadejo, 1962).

The description of phycomycosis given here is based on a series of 31 patients seen in Uganda, 21 of whom were examined personally by at least one of us. The others were traced through a retrospective survey of histological sections and hospital case-notes. This series includes the two cases previously reported from Uganda.

The clinical features of this lesion, which have been summarized by Burkitt et al. (1963), are characteristic. The condition had in fact been recognized as a clinical entity at Mulago Hospital for many years before the responsible organism was identified on histological section or growth in culture. The real nature of the lesion was not recognized until 1961, when Beaver identified the responsible organism in tissue removed from a child in Mulage Hospital (Jelliffe et al., 1961). One of

* From the Departments of Surgery, Medical Microbiology, and Paediatrics, Makerere College Medical School and Mulago Hospital, Kampala, Uganda. us (A.M.M.W.) at the same time recognized another case in Kampala as a mycosis and subsequently cultured the organism.

\section{Geographical Distribution}

As has been pointed out, the earliest reports came from Indonesia. The first recognition of the condition in Africa came from Uganda in 1961. Cases have now been observed from all four provinces in Uganda, and it would seem that the condition is widespread in that country (Fig. I). Recently it has also been reported from the northern Sudan, Kenya, and the Cameroons (Fig. II). Although only one case has been reported from Nigeria, some six further cases have been recognized at Ibadan (R. Harman, personal communication, 1962).

One of us (D. P. B.), on a recent visit to Ghana, recognized this lesion in a boy aged 7 years in Accra. A typical lesion involved the buttocks and encircled the anal canal, producing a firm stricture. Tissue removed for section showed the characteristic histological appearances, and the responsible organism was cultured.

It is unlikely that these are sporadic and isolated cases occurring across tropical Africa, and it would seem reasonable to expect that as the condition becomes increasingly recognized it will be found to be very widely distributed. So far there is no evidence of its occurrence in the Rhodesias or South Africa, although workers there have been aware of the features of this lesion.

\section{Clinical Aspects}

Age Incidence.-Seventeen of these patients $(55 \%$ of the total) were under the age of 9 , and only two apart from a record of "adult" were over the age of 20 (Fig. III). The few adult 